\title{
Changing glacial lakes and associated outburst floods risks in Nanda Devi Biosphere Reserve, Indian Himalaya
}

\author{
SURAJ MAL ${ }^{1} \&$ R. B. SINGH ${ }^{2}$ \\ 1 Department of Geography, Shaheed Bhagat Singh College, University of Delhi, Delhi-110017, India \\ suraj dse@rediffmail.com \\ 2 Department of Geography, Delhi School of Economics, University of Delhi, Delhi-110007, India
}

\begin{abstract}
Glacial lakes and associated outburst floods (GLOFs) have increased in the Himalayan region due to climate change during the last century that has led to huge losses to society. Therefore, the present study was undertaken to map glacial lakes, their increasing extent, and associated damage potential in Nanda Devi Biosphere Reserve (NDBR), Indian Himalaya. The glacial lakes were mapped on Landsat TM (3 November, 2009 and 6 November 2010) and Landsat MSS satellite images (15 November 1976 and 26 October 1979) to assess their changing area. Potential GLOFs sites have been identified and studied for their damage potentials using site characteristics and past occurrence of GLOFs. A total of 35 lakes were mapped, of which 14 lakes are located at more than $4500 \mathrm{~m}$. The size and damage potentials of lakes have increased. Some lakes grew so much that they merged to form a big lake. All of these are potential GLOFs and can cause severe damage to society.

Key words glacial lakes inventory; glacial lake outburst flood; climate change; Indian Himalaya
\end{abstract}

\section{INTRODUCTION}

Major glacio-hydrological changes have taken place in glacial and periglacial mountain regions in response to climate change due to their higher level of sensitivity (Barry 1990, Couture and Pollard 2007, Mal and Singh 2013). The high altitude mountain areas sensitively react to climate change due to the propensity for melting of surface and sub-surface ice (Huggel et al., 2002). As a result, certain geomorphic processes and events including glacial de-buttressing, slope failures and glacial lake outburst flood (GLOF) events have accelerated on recently deglaciated foreland, periglacial and further downstream regions (Quincey et al. 2005). These failures frequently turn out to be catastrophic to human society (Evans and Clague 1994) and their ill effects are often felt further downstream, e.g. GLOFs events and associated debris flow (Huggel et al. 2004). Such examples appear to be common across the Himalayan and other mountain ranges (Huggel et al. 2004, Bisht et al. 2002, 2011, Sah et al. 2005, Bajracharya et al. 2007, NDMA 2009).

Glacial lakes are common phenomena in mountain regions (Huggel et al. 2002). As per the estimates of Mool et al. (2001) and ICIMOD and APN (2005), there are more than 6100 glacial lakes, covering an area of about $790 \mathrm{~km}^{2}$ in the Hindu-Kush-Himalayan (HKH) Mountains. The Indian Himalayan Mountains alone have about 582 glacial lakes that cover an area of about 402 $\mathrm{km}^{2}$. The area and number of glacial lakes have increased in the Himalayan region due to climate change during the last century (Sah et al. 2005). However, there are not many studies about changing area of glacial lakes. The assessment of increasing glacial lakes and their interlinkages with GLOFs are of great importance in view of their great potential for causing major catastrophes to human society (Huggel et al. 2004). These lakes have been increasingly observed to breach out, leading to outburst floods and debris flows (Fujita et al. 2007). Consequently, assessing the increasing size of glacial lakes and their flooding risk becomes vitally crucial (Dobhal et al. 2013). Therefore the present study was undertaken to map glacial lakes, their increasing extent and associated damage potentials in Nanda Devi Biosphere Reserve (NDBR), Indian Himalaya. The NDBR is located in Uttarakhand state of India and lies between the geographic coordinates of $79^{\circ} 13^{\prime} \mathrm{E}$ to $80^{\circ} 17^{\prime} \mathrm{E}$ longitudes and $31^{\circ} 04^{\prime} \mathrm{N}$ to $30^{\circ} 06^{\prime} \mathrm{N}$ latitudes.

\section{DATA SOURCES AND METHODOLOGY}

A complete inventory of glacial lakes was conducted in NDBR through mapping on the recent Landsat TM5 satellite images (3 November 2009 and 6 November 2010) (based on Huggel et al. 2004, Quincey et al. 2005, Sah et al. 2005) in combination with ASTER GDEM2 elevation data. Some of the areas 
(lakes) were not visible in one satellite image due to heavy snow conditions, thus the image from the previous year was used to complete the inventory. The lakes were characterized for their elevation, latitude and longitude, types and area coverage based on Landsat satellite data and Digital Terrain Model (DTM). The elevation information of lakes has been determined from ASTER GDEM2 for the centroids of the lakes' polygons. Lakes located at more than $3500 \mathrm{~m}$ above m.s.l. and in glacial and periglacial areas were considered as glacial lakes. The lakes were classified into many types such as cirque lake, supraglacial lake, subglacial lake, end-moraine dammed, lateral-moraine dammed, medieval-moraine dammed and glacial ice-blocked based on their site characteristics. Major lakes were remapped on earlier MSS satellite images (15 November 1976 and 26 October 1979) to assess their changing characteristics using a change detection method. The increased area of glacial lakes, higher elevations, their types and locations are considered the results and indications of climate change. A few potential GLOFs sites have been studied for their damage potential using their site characteristics such as elevation, slope angle, lake types, etc. following Fujita et al. (2008). Assessment of damage potential of glacial lakes has been done in relation to previously occurred GLOFs in the study area. Some of the already occurred GLOFs in the study area originated from very small lakes, some of which could not even be identified on satellite images. Five GPS-aided field visits, along with intense site photography, were also made to different areas for verification of results. The field photographs were synchronized with GPS readings in order to provide them with latitude and longitude information. It helped to identify glacial lakes and slope failure events on satellite images. In addition, relevant literature, including research papers, monographs and research reports have also been consulted.

\section{RESULTS AND DISCUSSION}

\section{Evolution of GLOFs in NDBR}

The study suggests that the study region has a rich history of failures of glacial lakes and associated damage (Table 1). The Badrinath region in Alaknanda River valley has particularly experienced lake failures. However, these events have remained under-documented due to inaccessibility of Himalayan mountains (Srinivasan, 2013). Recently, a GLOF event was properly reported for the first time, i.e. Kedar Tal glacial lake outburst (17 June 2013) above the Kedarnath Shrine (Uttarakhand), as it hit the major pilgrim centre, i.e. Kedarnath and caused unprecedented damage. The GLOF claimed more than 5000 people and caused great damage to many settlements downstream including Kedarnath town and Rambara (Dobhal et al. 2013). In most cases, these events remain unreported, e.g. Gankhwi Gad outburst flood (2003) in Dhauli Ganga valley and many others. The moraine-dammed glacial lake on Gankhwi Gad in glacial foreland region of Gankhwi glacier outburst in 2002 and 2003, lead to heavy debris flow downstream and severe devastation of human property (Bisht et al., 2011). The Siagari village in Dhauli Ganga Valley was completely buried under debris material (Fig. 1). This GLOF occurred from a very small glacial lake and washed out an entire village. GLOFs from larger lakes have potential to cause great damages to society.

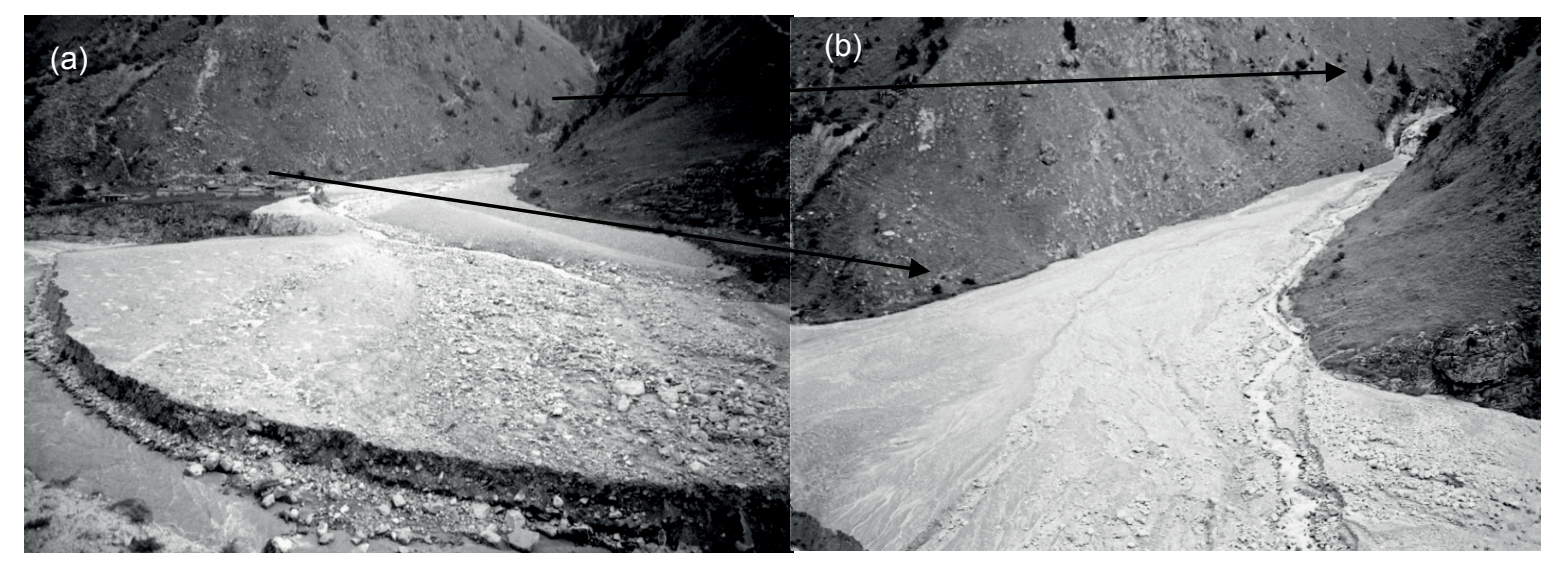

Fig. 1 (a) GLOF led debris flow in Gankhwi Gad (photo supplied by Prof. MPS Bisht), (b) The Siagari village was completely destroyed. 
Table 1 State of major GLOFs events in NDBR.

\begin{tabular}{|c|c|c|}
\hline Year & Areas & Causes and main event \\
\hline $\begin{array}{l}\text { April 19792; Feb- } \\
\text { March } 2002^{1}\end{array}$ & $\begin{array}{l}\text { Bamni Village near } \\
\text { Badrinath }\end{array}$ & $\begin{array}{l}\text { Avalanches blocked Alaknanda River and lake was formed, } \\
\text { which later breached above Bamni village near Badrinath. }\end{array}$ \\
\hline 20 July $1970^{3}$ and 4 & $\begin{array}{l}\text { Hanuman Chatti near } \\
\text { Badrinath and to } \\
\text { Hardwar }\end{array}$ & $\begin{array}{l}\text { About } 275 \mathrm{~mm} \text { rainfall (in few hours) caused landslide that } \\
\text { blocked river creating temporary lakes. Alaknanda and } \\
\text { Dhauli Ganga raised } 30-60 \text { and by } 15-20 \mathrm{~m} \text {, respectively } \\
\text { that burst out causing considerable loss of life }(381) \text {. }\end{array}$ \\
\hline 14 July $2007^{2}$ & $\begin{array}{l}\text { Alakapuri Glacier and } \\
\text { Badrinath }\end{array}$ & $\begin{array}{l}\text { Glacio-fluvial sediments blocked Alaknanda River that } \\
\text { burst out. A large area of Lakshmi Van and hanging bridge } \\
\text { at Mana were washed away. }\end{array}$ \\
\hline $1968^{3}$ and $1970^{3}$ & $\begin{array}{l}\text { Reni Village, Chamoli, } \\
\text { Uttarakhand }\end{array}$ & $\begin{array}{l}\text { The lake of about } 40 \mathrm{~m} \text { height in Rishi Ganga developed } \\
\text { due to landslide led damming of Rishi Ganga River. The } \\
\text { lake breached in July } 1970 \text { causing extensive damage. }\end{array}$ \\
\hline $2002-2003^{2}$ & Saigari Village & $\begin{array}{l}\text { Gankhwi River was blocked by sediments and debris. } \\
\text { GLOF occurred in } 2002 \text { and } 2003 \text { and completely } \\
\text { destroyed the Saigari village in Dhauli Ganga valley. }\end{array}$ \\
\hline
\end{tabular}

Source: ${ }^{1}$ Bisht et al. 2002, ${ }^{2} 2011 ;{ }^{3}$ NDMA 2009; ${ }^{4}$ Gulia 2007.

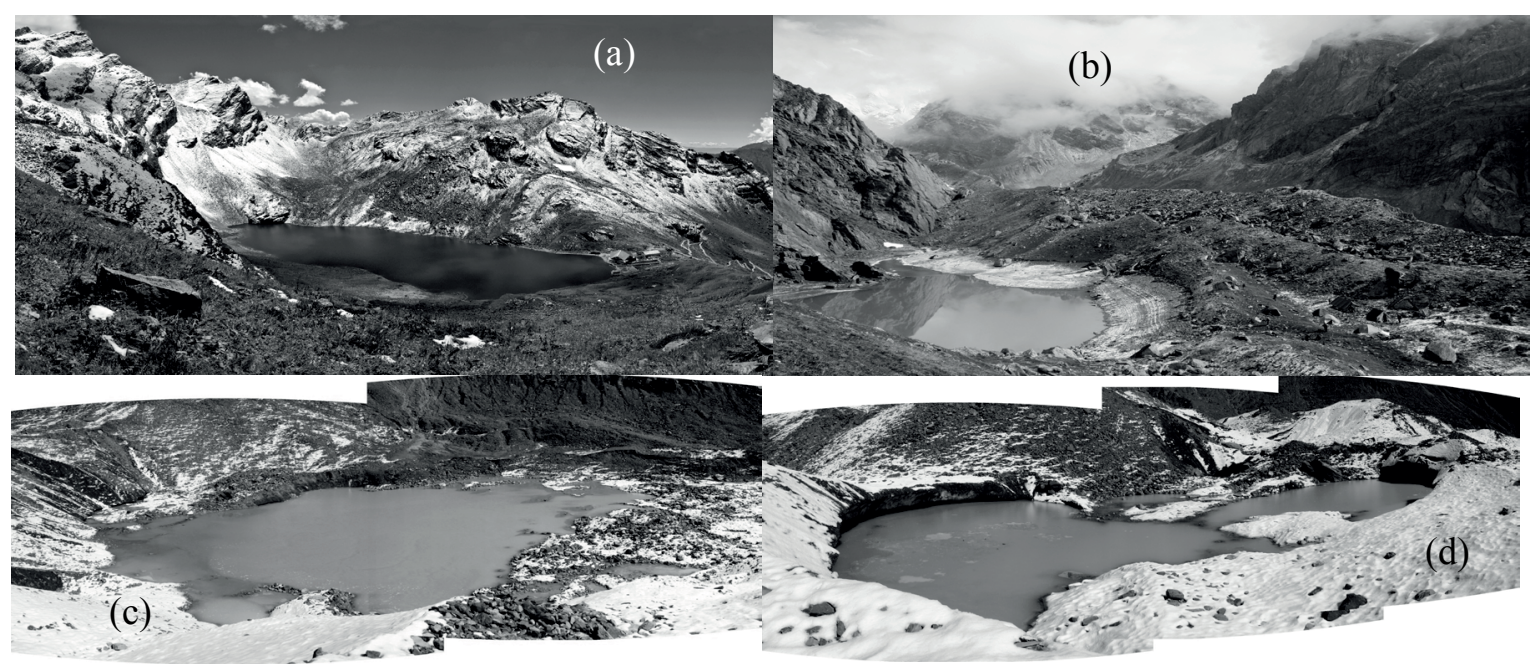

Fig. 2 Types of glacial lakes. (a) Cirque lake near Hemkund Sahib, (b) lateral moraine-dammed lake on Bankund glacier (June 2010, photo supplied by Ashutosh), (c) end-moraine dammed lake in foreland of Milam glacier (October 2009) and (d) supraglacial lake in ablation zone of Milam glacier (October 2009).

\section{Inventory and distribution of glacial lakes}

A total of 35 lakes could be identified and mapped on satellite images belonging to various types, including end-moraine dammed, cirque, lateral-moraine dammed, glacial-ice blocked and supraglacial lakes (Fig. 2). The criteria for the typology of lakes are their site characteristics. However, a few lakes in Saraswati River catchment could not be mapped, due to heavy snow cover and coarse spatial resolution $(30 \mathrm{~m})$ of satellite images. These lakes are clearly visible on Google Earth maps. Of the total 35 mapped lakes, 17 are supraglacial lakes, five cirque lakes, four lateral-moraine dammed, three endmoraines dammed and six are of other types. A few of the lakes are very large in size.

An unnamed lake on East Kamet glacier (supraglacial cum end-moraine) is the largest $\left(531028.52 \mathrm{~m}^{2}\right)$ glacial lake in NDBR. The other large lakes are Sitkeng (115 $\left.176.91 \mathrm{~m}^{2}\right)$, Hemkund (109 $\left.344.23 \mathrm{~m}^{2}\right)$, Geldhura (92 $\left.522.72 \mathrm{~m}^{2}\right)$ and Kagbhusandi $\left(80868.38 \mathrm{~m}^{2}\right)$. Of these, Sitkeng and Geldhura are end-moraine dammed type lakes and others belong to cirque types. The altitude and area of lakes are closely related. All the lakes are larger than $1270 \mathrm{~m}^{2}$ and most of them are located at high altitudes ( $>4000 \mathrm{~m})$ (Fig. 3). Three lakes are located at more than $5000 \mathrm{~m}$ above msl, 11 between 4500 to $5000 \mathrm{~m}, 14$ between 4000 to $4500 \mathrm{~m}$ and 7 are below $4000 \mathrm{~m}$. The highest altitude lake (unnamed, $5622 \mathrm{~m}$ ) is located at the base of Saraswati peaks of Saraswati River watershed and is of supraglacial 
type. The other two lakes at very high altitudes $(>5000 \mathrm{~m})$ are cirque (Unnamed_saraswati) and endmoraine dammed (Sitkang) types, respectively. The elevation of lakes increases towards the northern margins of NDBR (Fig. 4). Presence of different types of glacial lakes in higher elevations is an indication of glacial retreat caused by climate change.

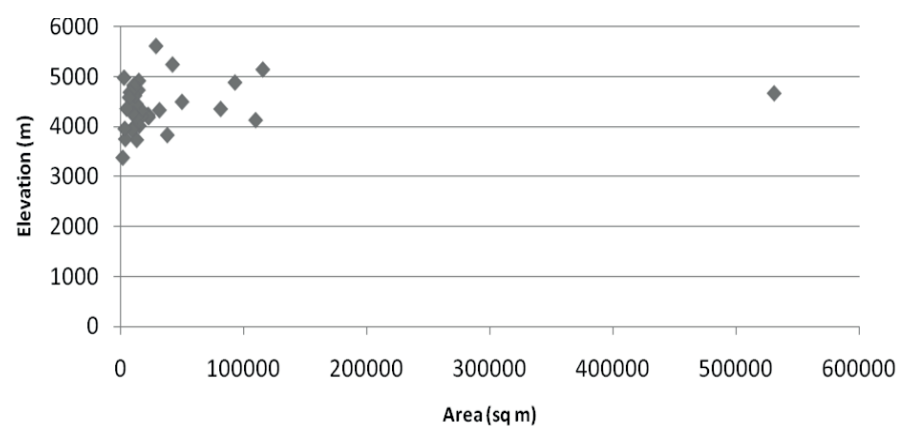

Fig. 3 Scatter plots of area of glacial lake $v s$ elevation. The area of glacial lakes has been derived from Landsat satellite TM5 images of 3 November 2009 and 6 November 2010 and elevation from ASTER GDEM2 Image.

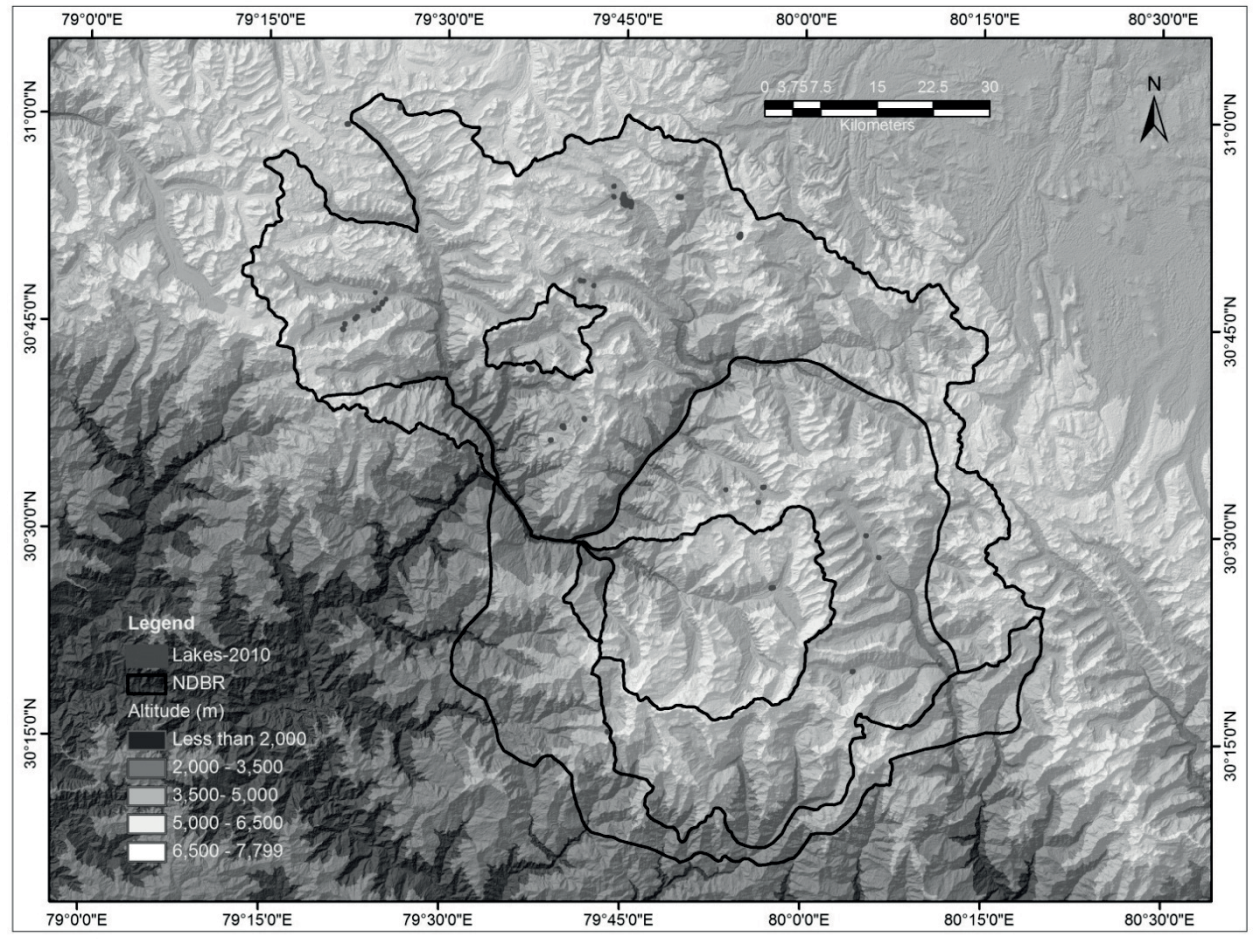

Fig. 4 Spatial distribution of glacial lakes in various altitudinal zones of NDBR, as mapped on Landsat 5 TM satellite images (3 November 2009 and 6 November 2010) (Background-ASTER GDEM2 Image).

\section{Increasing extent of glacial lakes and associated outburst flood risks}

The formation and development of glacial lakes are associated with the process of deglaciation and deglaciated foreland caused by climate change (Quincey et al. 2005, Fujita et al. 2008). The area and volume of water in glacial lakes increases due to increased water supply from retreating glaciers (Mool et al. 2001). All the remapped glacial lakes have been observed to increase over the period of 1976 and 2010 (Table 2). Unnamed lakes on East Kamet glacier, Sitkeng, Geldhura and Hemkund lakes significantly increased by areas of $79952.2,30430.9,29543.9$ and $27948.7 \mathrm{~m}^{2}$, respectively. There was minimal expansion observed in the area $\left(6573.8 \mathrm{~m}^{2}\right)$ of Kagbhusandi, the fourth largest lake of NDBR. Geldhura lake has expended rapidly but at a lower rate than the two largest lakes. There were some small lakes on East Kamet glacier that expanded to the extent that they merged 
and formed a big lake (Fig. 5). All the increasing glacial lakes are potential future GLOFs sites owing to their fragile physiographic and geomorphic conditions and will cause huge damage due to their association with nearby human settlements.

Table 2 Changing extents of glacial lakes- few representative examples from NDBR.

\begin{tabular}{|c|c|c|c|c|}
\hline Name & Lake Type & $\begin{array}{l}\text { Area }\left(\mathrm{m}^{2}\right) \\
1976\end{array}$ & $\begin{array}{l}\text { Area }\left(\mathrm{m}^{2}\right) \\
2010\end{array}$ & $\begin{array}{l}\text { Change } \\
\left(\mathrm{m}^{2}\right)\end{array}$ \\
\hline Kagbhusandi & Cirque & 74294.56 & 80868.38 & 6573.8 \\
\hline Sitkang & End_Moraine_Dammed & 84745.99 & 115176.91 & 30430.9 \\
\hline Un-named_(Kamet_gl) & $\begin{array}{l}\text { Supraglacial_End_Moraine_D } \\
\text { ammed }\end{array}$ & 451076.36 & 531028.52 & 79952.2 \\
\hline Hemkund_lake & Cirque & 81395.56 & 109344.23 & 27948.7 \\
\hline $\begin{array}{l}\text { Un- } \\
\text { named_(Nanda_devi_gl) }\end{array}$ & Lateral_Moraine_Dammed & 28104.94 & 49482.81 & 21377.9 \\
\hline Gel_dhura & End_Moraine_Dammed & 62978.82 & 92522.72 & 29543.9 \\
\hline Un-named_(Satopant_gl) & Lateral_Moraine_Dammed & 21336.30 & 31082.11 & 9745.8 \\
\hline
\end{tabular}

Source: Calculated from Landsat MSS (1976) and TM images (3 November 2009 and 6 November 2010).

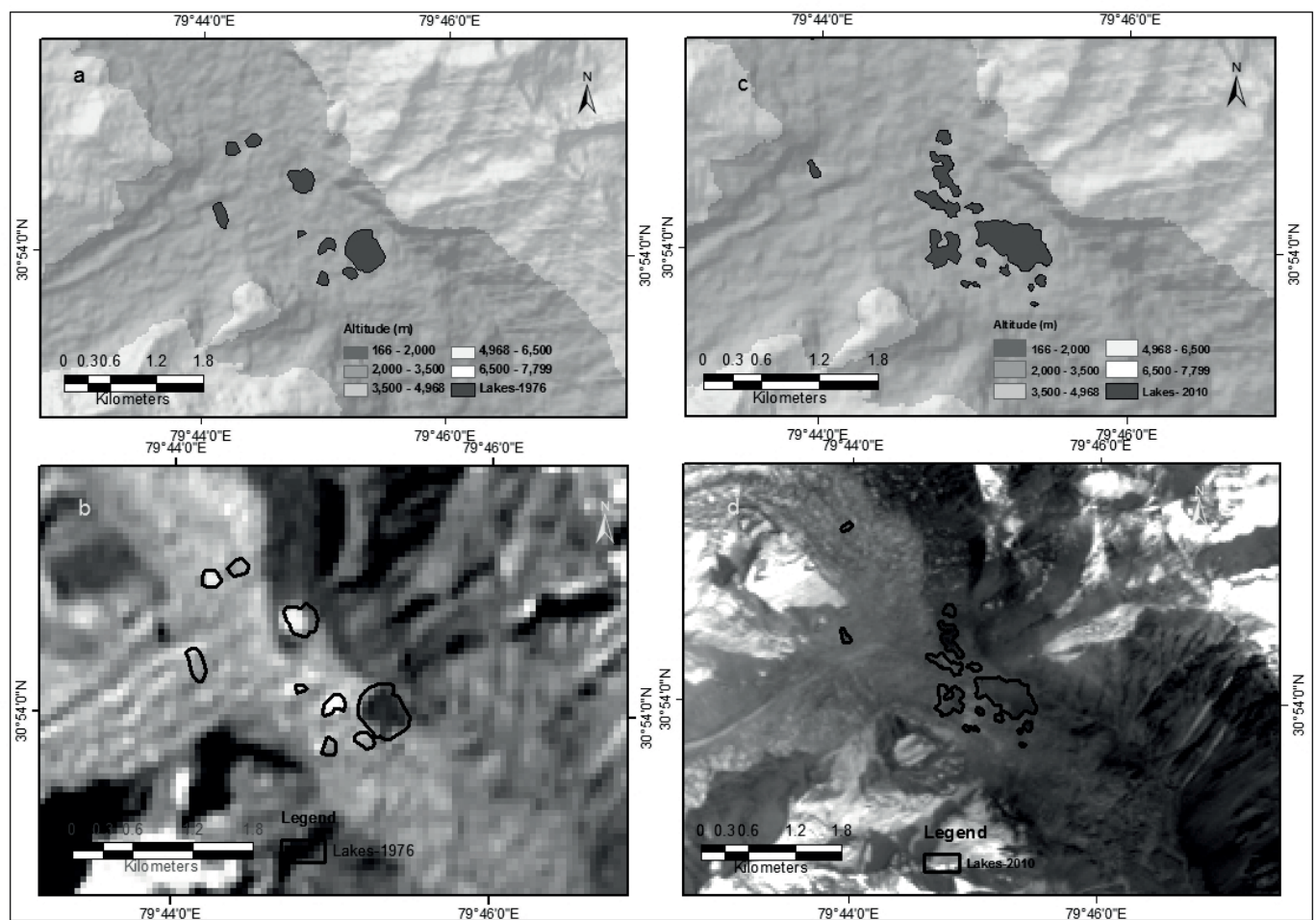

Fig. 5 Changing extent of an unnamed supraglacial-cum-endmoraine dammed lake and increasing potential of GLOF on East Kamet glacier. (a) lake in 1976 on Landsat MSS 1976, and (b) lake in 2010 on Landsat TM 2010.

Kagbhusandi $\left(80868.38 \mathrm{~m}^{2}\right)$ and Hemkund $\left(109344.23 \mathrm{~m}^{2}\right)$ lakes are also such high altitude $(4363 \mathrm{~m})$ increasing cirque lakes that are potential hazards for settlements located in downstream areas of the Laxman Ganga catchment. The lakes are frequently affected by avalanches activities that produce waves in lake. The larger waves may sometimes overtop the lake outlet or lead to its breaching, draining the area located further downstream. Sometimes, lakes grow in size to an extent that the terminal moraines fail to hold the water and breach out (Mool et al., 2001; Quincey et al., 2005). Such breaching and failures produce huge flooding of water and debris flow, and cause unprecedented damage to downstream areas and settlements. The human settlements of Ghangaria, 
Bhundyar, Pulna and Govind Ghat are located downstream of lakes and are risk prone. These settlements will be completely washed away if the lakes breach out, as in case of Gankhwi Gad burst flood. There are already many such un-documented cases in NDBR.

\section{CONCLUSION}

The climate change has deglaciated higher elevations of mountains across the world. Consequently, glacial lakes have increased in number and their size expanded continuously. These glacial lakes have been increasingly observed to breach out and cause unprecedented damage to society. Some of the growing lakes have become potential GLOFs sites. These are an additional source of damage to human society that has come up in recent years as a result of climate change. GLOFs are occurring on a regular basis leading to huge damages. It is therefore needed to carryout complete assessment of potential GLOFs in order to provide the community and society a better warning and management system.

\section{REFERENCES}

Bajracharya, S. R., Mool, P. K. and Shrestha, B. R. (2007) Impact of climate change on Himalayan glaciers and glacial lakes. International Center for Integrated Mountain Development (ICIMOD), Kathmandu.

Barry, R. G. (1990) Changes in mountain climate and glacio-hydrological responses. Mountain Research and Development 10(2), $161-170$.

Bisht, M. P. S., Mehta, M. and Nautiyal, S.K. (2002) A report on geomorphic hazards around Badrinath Area (Uttaranchal) and innovative control measures proposed, NDBR project. Department of Geology, HNB Garhwal University, Uttarakhand.

Bisht, M. P. S., Mehta, M. and Nautiyal, S. K. (2011) Impact of depleting glaciers on the Himalayan biosphere reserve- a case study of Nanda Devi Biosphere Reserve, Uttarakhand Himalaya. In: Mountain Resource Management: Application of Remote Sensing and GIS (ed. by M. P. S. Bisht and D. Pal), 17-31. Transmedia Publication, Srinagar, Uttarakhand.

Couture, N. J. and Pollard, W. H. (2007) Modelling geomorphic response to climatic change. Climatic Change 85, $407-431$.

Dobhal, D.P., et al. (2013) Kedarnath disaster: facts and plausible causes. Current Science 105, $171-174$.

Evans, S. G. and Clague, J. J. (1994) Recent climatic change and catastrophic geomorphic processes in mountain environments. Geomorphology 10, 107-128.

Fujita, K., et al. (2008) Performance of ASTER and SRTM DEMs and their potential for assessing glacial lakes in the Lunana region, Bhutan Himalaya. Journal of Glaciology 54, 220-228.

Gulia, K. S. (2007) Discovering Himalaya: Tourism of Himalayan Region. ISHA Books, Delhi.

Huggel, C., Kaab, A. and Salzmann, N. (2004) GIS-Based modeling of glacial hazards and their interactions using Landsat-TM and IKONOS imagery. Norwegian Journal of Geography 58, 61-73.

Huggel, C., et al. (2002) Remote-sensing based assessment of hazards from glacier lake outbursts: a case study in the Swiss Alps. Journal of Canadian Geotechnical Journal 39, 316-330.

ICIMOD and APN (2005) Inventory of glaciers and glacial lakes and the identification of potential glacial lake outburst floods (GLOFs) affected by global warming in the mountains of India, Pakistan and China/Tibet Autonomous region. International Centre for Integrated Mountain Development (ICIMOD) and Asia-Pacific Network for Global Change Research (APN).

Mal, S. and Singh, R. B. (2013) Differential recession of glaciers in Nanda Devi Biosphere Reserve, Garhwal Himalaya, India. In: Cold and Mountain Region Hydrological Systems under Climate Change: Towards Improved Projections. Proceedings of H02, IAHS-IAPSO-IASPEI Assembly, Gothenburg, Sweden. IAHS Publ. 360, 71-76. IAHS Press, Wallingford, UK.

Mool, P. K., Bajracharya, S. R. and Joshi, S. P. (2001) Inventory of glaciers, glacial lakes and glacial lake outburst floods monitoring and early warning systems in the Hindu Kush-Himalayan Region, Nepal. United Nations Environment Programme Regional Resource Centre UNEP (UNEP)/Asia and the Pacific (RRC-AP) International Centre for Integrated Mountain Development (ICIMOD), Mountain Environment and Natural Resources' Information Systems.

NDMA (2009) National Disaster Management Guidelines_-Management of Landslides and Snow Avalanches, 2009. Publication of National Disaster Management Authority, Government of India. New Delhi.

Quincey, D.J., et al. (2005) Optical remote sensing techniques in high-mountain environments: application to glacial hazards. Progress in Physical Geography 29(4), 475-505.

Sah, M., et al. (2005) Uttaranchal Himalaya, India: inventory of glaciers and glacial lakes and the identification of potential glacial lake outburst floods (GLOFs) affected by global warming in the mountains of himalayan region. Wadia Institute of Himalayan Geology (WIHG), International Centre for Integrated Mountain Development (ICIMOD), Asia-Pacific Network for Global Change (APN), Global Change SysTem for Analysis, Research, and Training (START) and United Nation's Environmental Programme (UNEP).

Srinivasan, J. (2013) Predicting and managing extreme rainfall. Current Science 105(1), 7-8. 